\title{
Effect of the Antilipolytic Nicotinic Acid Analogue Acipimox on Whole-Body and Skeletal Muscle Glucose Metabolism in Patients with Non-insulin-dependent Diabetes Mellitus
}

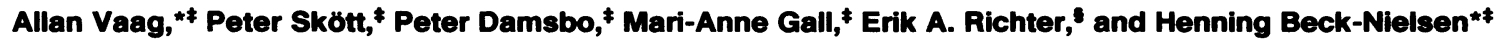 \\ ${ }^{*}$ Department of Internal Medicine M, Odense University Hospital, DK-5000 Odense, Denmark; ${ }^{\ddagger}$ Hvidöre Hospital, DK-2950 \\ Klampenborg, Denmark; and ${ }^{\$}$ August Krogh Institute, University of Copenhagen, DK-2100 Copenhagen, Denmark
}

\begin{abstract}
Increased nonesterified fatty acid (NEFA) levels may be important in causing insulin resistance in skeletal muscles in patients with non-insulin-dependent diabetes mellitus (NIDDM). The acute effect of the antilipolytic nicotinic acid analogue Acipi$\operatorname{mox}(2 \times 250 \mathrm{mg})$ on basal and insulin-stimulated $(3 \mathrm{~h}, 40$ $\mathrm{mU} / \mathrm{m}^{2}$ per $\mathrm{min}$ ) glucose metabolism was therefore studied in 12 patients with NIDDM. Whole-body glucose metabolism was assessed using $\left[3-{ }^{3} \mathrm{H}\right]$ glucose and indirect calorimetry. Biopsies were taken from the vastus lateralis muscle during basal and insulin-stimulated steady-state periods. Acipimox reduced NEFA in the basal state and during insulin stimulation. Lipid oxidation was inhibited by Acipimox in all patients in the basal state $\left(20 \pm 2\right.$ vs. $33 \pm 3 \mathrm{mg} / \mathrm{m}^{2}$ per $\left.\mathrm{min}, P<0.01\right)$ and during insulin infusion $\left(8 \pm 2\right.$ vs. $17 \pm 2 \mathrm{mg} / \mathrm{m}^{2}$ per $\mathrm{min}, P$ $<0.01)$. Acipimox increased the insulin-stimulated glucose disposal rate $\left(369 \pm 49\right.$ vs. $262 \pm 31 \mathrm{mg} / \mathrm{m}^{2}$ per $\left.\min , P<0.01\right)$, whereas the glucose disposal rate was unaffected by Acipimox in the basal state. Acipimox increased glucose oxidation in the basal state $\left(76 \pm 4\right.$ vs. $50 \pm 4 \mathrm{mg} / \mathrm{m}^{2}$ per min, $\left.P<0.01\right)$. During insulin infusion Acipimox increased both glucose oxidation $\left(121 \pm 7 \mathrm{vs.} 95 \pm 4 \mathrm{mg} / \mathrm{m}^{2}\right.$ per $\left.\mathrm{min}, P<0.01\right)$ and nonoxidative glucose disposal $\left(248 \pm 47\right.$ vs. $167 \pm 29 \mathrm{mg} / \mathrm{m}^{2}$ per $\mathrm{min}, P$ $<0.01)$. Acipimox enhanced basal and insulin-stimulated muscle fractional glycogen synthase activities $(32 \pm 2$ vs. $25 \pm 3 \%, P$ $<0.05$, and $50 \pm 5$ vs. $41 \pm 4 \%, P<0.05)$. Activities of muscle pyruvate dehydrogenase and phosphofructokinase were unaffected by Acipimox. In conclusion, Acipimox acutely improved insulin action in patients with NIDDM by increasing both glucose oxidation and nonoxidative glucose disposal. This supports the hypothesis that elevated NEFA concentrations may be important for the insulin resistance in NIDDM. The mechanism responsible for the increased insulin-stimulated nonoxidative glucose disposal may be a stimulatory effect of Acipimox on glycogen synthase activity in skeletal muscles. (J. Clin. Invest. 1991. 88:1282-1290.) Key words: glucose-fatty acid cycle - glycogen synthase • insulin resistance • phosphofructokinase • pyruvate dehydrogenase
\end{abstract}

Address reprint requests to Dr. Vaag, Department of Internal Medicine M, Odense University Hospital, Sdr. Boulevard, DK-5000 Odense, Denmark.

Received for publication 4 September 1990 and in revised form 18 April 1991.

J. Clin. Invest.

(c) The American Society for Clinical Investigation, Inc.

$0021-9738 / 91 / 0 / 1282 / 09 \$ 2.00$

Volume 88, October 1991, 1282-1290

\section{Introduction}

Patients with non-insulin-dependent diabetes mellitus (NIDDM) ${ }^{1}$ are characterized by resistance to insulin-stimulated glucose uptake in peripheral tissues (predominantly skeletal muscles), and it is generally believed that this defect plays an important role in the pathogenesis of the syndrome. Patients with NIDDM often have elevated fasting and postprandial concentrations of nonesterified fatty acids (NEFA) in plasma $(1,2)$. This may be due to an increased rate of lipolysis in adipose tissues and skeletal muscles in patients with NIDDM. A significant direct correlation between degree of plasma NEFA concentration and magnitude of fasting hyperglycemia has been documented in patients with $\operatorname{NIDDM}(3,4)$. Furthermore, elevations in plasma NEFA concentration have been shown to lower insulin-stimulated glucose uptake in normal individuals $(5,6)$. Thus, it has been hypothesized that insulin resistance in patients with NIDDM may be caused by or may be partly due to elevated NEFA concentrations in plasma and skeletal muscles. Recently, this hypothesis has been further documented by Reaven et al. (7), who demonstrated a lowering effect of plasma glucose in streptozotocin-induced diabetic rats by two different antilipolytic agents, nicotinic acid (NA) and phenylisopropyladenosine (7). NA was shown to increase in vivo insulin-stimulated glucose uptake in peripheral tissues, and both NA and PIA were shown to increase in vitro insulinstimulated glucose uptake in isolated adipocytes.

The mechanisms that control the relationship between fatty acid and glucose utilization in human skeletal muscle are not clear. The classic glucose-fatty acid cycle, demonstrated by Randle et al. (8) in isolated rat hearts and hemidiaphragms, involves an inhibitory effect of NEFA on glycolysis and pyruvate oxidation. In this model, no effect of NEFA on glycogen synthesis was demonstrated. The inhibitory effect of NEFA on glycolysis and glucose oxidation was explained by the same group to be caused by a buildup of mitochondrial citrate and acetyl-coenzyme $\mathrm{A}(\mathrm{CoA})$, and a rise in the cytoplasmic NADH/NAD ratio $(9,10)$. The increase in acetyl CoA/CoA ratio activates pyruvate dehydrogenase kinase $(11,12)$, which then phosphorylates and inactivates the pyruvate dehydrogenase (PDH) complex. Accumulation of citrate causes an inhibition of phosphofructokinase (PFK) (13), thus slowing down the

1. Abbreviations used in this paper: F-6-P and F-6,1-dP, fructose 6phosphate and fructose 1,6-diphosphate; G-6-P, glucose 6-phosphate; GS, glycogen synthase; HGP, hepatic glucose production; NA, nicotinic acid; NEFA, nonesterified fatty acid(s); NIDDM, non-insulin-dependent diabetes mellitus; PDH, PDHa, and PDHt, pyruvate dehydrogenase, active PDH, and total PDH; PFK, phosphofructokinase; UDPG, uridine diphosphate glucose. 
glycolytic flux. This may cause an accumulation of glucose-6phosphate (G-6-P), which again inhibits the activity of hexokinase in turn causing an intracellular accumulation of free glucose that decreases the gradient of glucose across the cell membrane. These mechanisms, however, have never been demonstrated to operate in human skeletal muscles.

Acipimox (5-methyl-pyrazine carboxylic acid 4-oxide, Farmitalia Carlo Erba, Milano, Italy) is a new potent and long-acting $(8 \mathrm{~h})$ antilipolytic drug, which has been derived from NA (14). By lowering plasma and possibly skeletal muscle concentrations of NEFA, Acipimox may have a potential beneficial effect on glucose metabolism in patients with NIDDM. Furthermore, besides being more long acting, Acipimox may have the potential advantage over nicotinic acid that it causes a minor "rebound" effect on lipolysis (15). The aim of this study was to evaluate the acute effect of Acipimox on basal and insulinstimulated whole-body glucose metabolism in patients with NIDDM. Furthermore, by taking biopsies from skeletal muscles, we intended to establish whether changes in key enzyme activities in this tissue could be responsible for any of the in vivo effects of Acipimox. Thus, by using Acipimox, we intended to study the importance of and the possible mechanisms behind the glucose-fatty acid cycle in human subjects with NIDDM.

\section{Methods}

\section{Subjects}

12 patients with NIDDM were included in the study. Their characteristics are given in Table $I$. The patients were obese and most of the subjects $(n=7)$ had fasting plasma triglyceride concentrations above the upper normal limit $(2.20 \mathrm{mmol} / \mathrm{liter})$. Five patients were treated with diet alone and seven patients were treated with diet and oral hypoglycemic drugs (sulfonylurea or metformin). During the study period, patients were on a weight-maintaining diet consisting of $\sim 55 \%$ carbohydrate, $15 \%$ protein, and $30 \%$ fat. Oral hypoglycemic drugs were withdrawn at least $36 \mathrm{~h}$ before each metabolic study. Five patients were treated for hypertension. In these patients, antihypertensive drugs were withdrawn $4 \mathrm{wk}$ before the first investigation and until the end of the study. During this period, diastolic blood pressures did not exceed 110 $\mathrm{mm} \mathrm{Hg}$. None of the subjects had clinical evidence of cardiac, hepatic, or renal disease or endocrine disorders other than diabetes. Furthermore, there was no evidence of diabetic neuropathy, nephropathy, or

Table I. Clinical Characteristics of the Study Patients

$\begin{array}{lc}\text { Number (females/males) } & 12(2 / 10) \\ \text { Age }(y r) & 55.8 \pm 2.3 \\ \text { Duration of diabetes }(y r) & 6.9 \pm 1.7 \\ \text { Height }(\mathrm{m}) & 1.74 \pm 0.02 \\ \text { Weight }(\mathrm{kg}) & 90.4 \pm 4.5 \\ \text { Body mass index }\left(\mathrm{kg} / \mathrm{m}^{2}\right) & 29.6 \pm 1.0 \\ \text { Glycohemoglobin }\left(\mathrm{HbA}_{\mathrm{ic}}, \%\right)^{*} & 8.4 \pm 0.6 \\ \text { Fasting plasma glucose }(\mathrm{mmol} / \text { liter }) & 10.5 \pm 1.1 \\ \text { Fasting plasma insulin }(\mathrm{nmol} / \mathrm{liter}) & 0.11 \pm 0.01 \\ \text { Fasting plasma C-peptide }(\mathrm{nmol} / \mathrm{liter}) & 0.94 \pm 0.11 \\ \text { Fasting plasma NEFA }(\mathrm{mmol} / \mathrm{liter}) & 0.64 \pm 0.06 \\ \text { Fasting plasma triglyceride }(\mathrm{mmol} / \mathrm{liter}) & 2.57 \pm 0.45 \\ \text { Fasting plasma cholesterol }(\mathrm{mmol} / \mathrm{liter}) & 6.1 \pm 0.2\end{array}$

Data are mean \pm SE. * Normal range 4.1-6.1\%. proliferative retinopathy. Patients were informed of the nature and the purpose of the study before their voluntary consent to participate was obtained. The study was approved by the regional ethical committee and the procedure was performed according to the principles of the Helsinki Declaration.

\section{Study design}

The study was designed as a double-blind crossover study. An isoglycemic insulin clamp $\left(40 \mathrm{mU} / \mathrm{m}^{2}\right.$ per $\left.\mathrm{min}\right)$ was performed on two separate days in random order (Fig. 1). The second study in each patient was carried out 4-6 wk apart from the first study. On one day patients received Acipimox $(2 \times 250 \mathrm{mg})$ and on the other day they received placebo. Acipimox or placebo tablets were given $150 \mathrm{~min}$ before the basal steady state period and $150 \mathrm{~min}$ before the insulin-stimulated steady-state period. The studies were carried out in combination with indirect calorimetry and infusions of $\left[3-{ }^{3} \mathrm{H}\right]$ glucose to allow quantification of respiratory gas exchange, total glucose turnover, and hepatic glucose production (HGP). On both study days, muscle biopsies were performed from the vastus lateralis muscle after the basal steady-state period and after the insulin-stimulated steady state period (Fig. 1).

\section{In vivo methods}

Isoglycemic insulin clamp. Patients were admitted to Hvidöre Hospital the night before each clamp study. All studies were started at $0730 \mathrm{~h}$ after a 10-h overnight fast. Acipimox or placebo was given according to the procedure outlined above. A polyethylene catheter was inserted into an antecubital vein for infusion of test substances. Another polyethylene catheter was inserted into a contralateral wrist wein for blood sampling. This hand was placed and maintained in a heated plexiglas box to obtain arterialized venous blood (16). Each clamp study was preceded by a 120 -min period for basal measurements (Fig. 1). Insulin (Actrapid, Novo-Nordisk, Bagsvaerd, Denmark) was infused for 180 min at a constant rate of $40 \mathrm{mU} / \mathrm{m}^{2}$ per min and plasma glucose was clamped with a variable infusion of $20 \%$ glucose at the fasting plasma glucose concentration (isoglycemic clamp) (17). The insulin infusion rate $40 \mathrm{mU} / \mathrm{m}^{2}$ per min was chosen in order to obtain high physiological plasma insulin concentrations. Blood glucose concentration was monitored in arterialized blood with a continuous glucose analyzer (Biostator CGIIS, Life Science Instruments, Miles Laboratories, Elkhart, IN) connected to a forearm vein on the "sampling" arm. The glucose analyzer of the biostator was calibrated at least every $30 \mathrm{~min}$ during study periods using an automated glucose oxidase method (Glucose Analyzer 2, Beckman Instruments, Inc., Fullerton, CA). Steadystate periods were defined as the last $30 \mathrm{~min}$ during basal measurements ( -30 to $0 \mathrm{~min}$ ) and the last $30 \mathrm{~min}$ during insulin-stimulated measurements (150-180 min). Urinary glucose excretion was measured during each clamp study in order to correct for this when calculating total peripheral glucose uptake.

Tritiated glucose. The glucose clamp studies were combined with a primed continuous infusion of $\left[3-{ }^{3} \mathrm{H}\right] \mathrm{glucose}$ (New England Nuclear, Boston, MA) (Fig. 1). In order to ensure achievement of isotope equilibrium, the continuous infusion of $\left[3-{ }^{3} \mathrm{H}\right]$ glucose $(0.22 \mu \mathrm{Ci} / \mathrm{min})$ was begun 90-120 min before measurements of glucose turnover were performed, and the priming dose of $\left[3-{ }^{3} \mathrm{H}\right]$ glucose was increased in proportion to fasting hyperglycemia according to the formula: priming dose $=22 \mu \mathrm{Ci} \times$ plasma glucose concentration $(\mathrm{mmol} / \mathrm{liter}) / 5(\mathrm{mmol} /$ liter) (18). The radiochemical purity of the tracer was $100 \%$ as determined by HPLC. During steady-state periods, blood samples were drawn in fluoride-treated tubes every $10 \mathrm{~min}$ for determination of plasma glucose and plasma $\left[3-{ }^{3} \mathrm{H}\right] \mathrm{glucose}$ activity. During the rest of the study period, plasma glucose and $\left[3-{ }^{3} \mathrm{H}\right]$ glucose activity were measured every $30 \mathrm{~min}$.

Indirect calorimetry. Indirect calorimetry was performed using a computerized flowthrough canopy gas analyzer system (Deltatrac, Datex, Helsinki, Finland). Briefly, air is suctioned at a rate of $40 \mathrm{liter} / \mathrm{min}$ through a canopy placed over the head of the subject. Samples of inspired and expired air are analyzed for oxygen concentration by using a paramagnetic differential oxygen sensor and for carbon dioxide by us- 


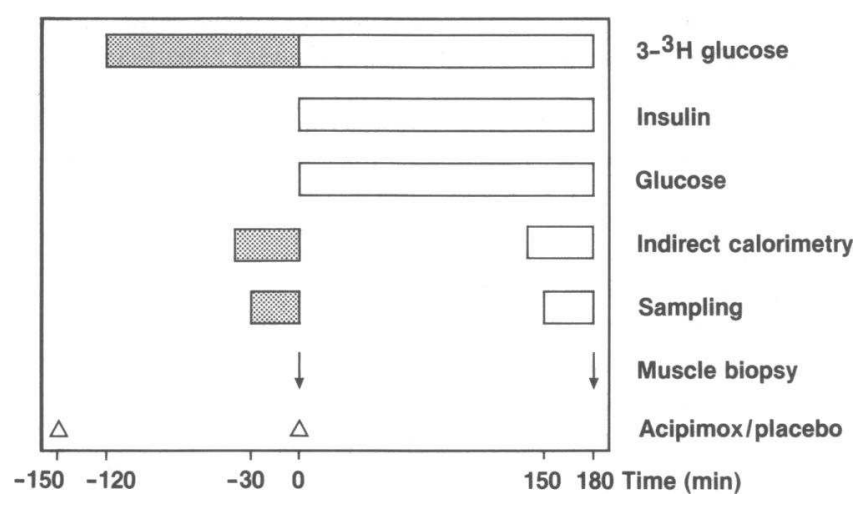

Figure 1. Experimental study design. Plasma glucose was clamped at the fasting glucose concentration during insulin infusion (isoglycemic clamp procedure). Each isoglycemic clamp study was preceded by a 120-min period for basal measurements (darkened bars). Insulin was infused for $180 \mathrm{~min}$ at a rate of $40 \mathrm{mU} / \mathrm{m}^{2}$ per min. Steady-state measurements of glucose turnover were made, and indirect calorimetry was carried out during last $30 \mathrm{~min}$ of basal and clamp periods. During this time, blood was analyzed for insulin, C-peptide, triglycerides, NEFA and lactate every $10 \mathrm{~min}$. Muscle biopsies were taken from the vastus lateralis muscle in the basal state and after $180 \mathrm{~min}$ of insulin infusion. Each subject was studied twice in randomized order with or without $2 \times 250 \mathrm{mg}$ of Acipimox.

ing an infrared carbon dioxide sensor. Signals from the gas analyzers are processed by the computer and oxygen consumption and carbon dioxide production are calculated and recorded once per minute. After an equilibration period of $10 \mathrm{~min}$, the average gas exchange rates recorded over the two 30-min steady-state periods (Fig. 1) were used to calculate rates of glucose oxidation, lipid oxidation, and energy expenditure as previously described $(19,20)$. The $\mathrm{CO}_{2}$ concentrations did not exceed $1 \%$ at any time point during the steady-state measurements. The protein oxidation rate was estimated from urinary urea nitrogen excretion ( $1 \mathrm{~g}$ of nitrogen $=6.25 \mathrm{~g}$ of protein) and corrected for changes in pool size (21).

Muscle biopsy. Muscle biopsies were performed with a modified Bergström needle (including suction) under local anesthesia. The biopsies were rapidly (within 10-15 s) frozen in liquid nitrogen, where they were stored for later analysis. Before the biochemical analysis was performed, samples were freeze-dried and dissected free of visible connective tissue, fat, and blood.

Calculations. During the steady-state periods, glucose turnover rates (HGP and total peripheral glucose uptake) were calculated at 10-min intervals using Steele's non-steady-state equations (22). Nonsteady-state equations were used during basal measurements because of spontaneous declining plasma glucose concentrations on both study days in most patients. In these calculations, the distribution volume of glucose was taken as $200 \mathrm{ml} / \mathrm{kg}$ body weight and the pool fraction as 0.65 (23). Negative rates of HGP were calculated in most patients during insulin-stimulated steady-state periods. Such underestimation of glucose turnover by the tracer method is largely accounted for by a model error emerging at high rates of glucose metabolism (24). We took the negative numbers to indicate a nil HGP. Because HGP was fully suppressed during insulin infusion, the infusion rates of exogenous glucose (molar values) were equal to total peripheral glucose uptake. Total peripheral glucose uptake was corrected for urinary glucose excretion. Nonoxidative glucose metabolism was calculated as the difference between total body glucose uptake and glucose oxidation, as determined by indirect calorimetry.

\section{In vitro methods}

Glycogen and metabolite concentrations in muscle biopsies. Glycogen was measured as glucose residues after hydrolysis of the muscle sam- ples, in $1 \mathrm{M} \mathrm{HCl}$ at $100^{\circ} \mathrm{C}$ for $2 \mathrm{~h}(25)$. Glucose, G-6-P, and lactate were measured fluorometrically on neutralized perchloric acid extracts (25). The intracellular concentrations of free glucose, G-6-P, and lactate were calculated as millimoles per liter intracellular water, assuming an extracellular water content in the biopsies of $0.3 \mathrm{liter} / \mathrm{kg}$ dry weight and an intracellular water content of $2.8 \mathrm{liter} / \mathrm{kg}$ dry weight $(26,27)$. Intracellular concentrations of free glucose and lactate were corrected for extracellular concentrations using the above assumptions of intracellular and extracellular water content in the biopsies.

Muscle enzyme activities. Extraction of muscle samples and assays for glycogen synthase (GS), PDH, and PFK activities were performed as previously described by Mandarino et al. (28).

PDH assays were performed by a modification of the method of Hagg et al. (29), based on the technique of Blass et al. (30). Briefly, PDH activity was determined in the presence of low $(50 \mu \mathrm{M})$ and high $(10$ $\mathrm{mM}$ ) magnesium concentrations to determine active ( $\mathrm{PDHa}$ ) and total (PDHt) enzyme activity. PDH activity was expressed as picomoles of pyruvate oxidized per minute per milligram extract protein. The fractional activity of PDH is defined as the proportion of total enzyme that is active (PDHa/PDHt). This measure has been used as a measure of the extent of activation of PDH in vivo (31).

GS was assayed by a modification of the method of Thomas et al. (32). GS activity was assayed in the presence of a near-physiological concentration of $(0.1 \mathrm{mM})$ and in the presence of a high concentration of G-6-P (10 mM) to determine maximal enzyme activity. The total concentration of uridine diphosphate glucose $\left(\left[{ }^{14} \mathrm{C}\right] \mathrm{UDPG}+\right.$ cold UDPG) in the reaction mixture was $0.31 \mathrm{mM}$. GS activity was expressed as nanomoles of UDPG incorporated into glycogen per minute per milligram extract protein. Fractional velocity that is thought to reflect the proportion of total GS present that is active in vivo was calculated as the ratio between GS activity assayed at $0.1 \mathrm{mM} \mathrm{G-6-P}$ and $10 \mathrm{mM}$ G-6-P.

PFK activity was assayed spectrophotometrically in supernatants of muscle extracts by a modification of the method of Beutler (33). The assay coupled the conversion of fructose 6-phosphate (F-6-P) to fructose 1,6-diphosphate (F-1,6-dP) with the oxidation of NADH by means of a series of enzymatic steps including aldolase, triose phosphate isomerase, and $\alpha$-glycerolphosphate dehydrogenase. Activity of PFK was assayed in the presence of a near-physiological concentration of F-6-P $(0.1 \mathrm{mM})$ and in the presence of a high concentration of F-6-P (2.0 $\mathrm{mM}$ ) to determine the maximal activity of the enzyme. PFK activity was expressed as nanomoles of F-6-P converted to F-1,6-dP per minute per milligram extract protein.

Protein content of the extracts was determined by the method of Lowry et al. (34).

Analytical determinations. Glucose in plasma and urine was determined by a hexokinase method (35). Tritiated glucose activity was measured as previously described $(18,36)$. Plasma insulin $(37)$ and C-peptide (38) concentrations were measured with radioimmunological methods. Free fatty acids (NEFA) in plasma were determined by the method of Itaya and Michio (39) and lactate by the method of Passonneau (40). Plasma concentrations of glucose, insulin, C-peptide, NEFA, and lactate were measured every 10 min during the two steadystate periods. $\mathrm{HbA}_{\mathrm{ic}}$ was measured by isoelectric focusing (41), normal range $4.1-6.1 \%$.

Statistical analysis. Nonparametric statistical methods (Wilcoxon test for paired data and Spearman's rho (42) for correlation analysis) were employed in analysis of data. $P$ values $<0.05$ were considered significant. Data in text and figures are presented as the mean \pm SE.

\section{Results}

Plasma glucose, insulin, and C-peptide concentrations are given in Table II. Plasma glucose concentrations were similar on the two study days. A spontaneous decline in plasma glucose concentration was observed during the basal period (0$120 \mathrm{~min}$ ) on both study days. Although the decline was slightly 
Table II. Plasma Glucose, Insulin, and C-peptide Concentrations during Studies

\begin{tabular}{lllll}
\hline & & Placebo & Acipimox & \\
\hline Glucose & Fasting & $10.5 \pm 1.1$ & $11.3 \pm 1.1$ & NS \\
$\quad$ (mmol/liter) & Basal & $10.3 \pm 1.0$ & $10.8 \pm 1.1$ & NS \\
& Insulin & $10.3 \pm 1.1$ & $11.0 \pm 1.2$ & NS \\
Insulin & Fasting & $0.11 \pm 0.01$ & $0.12 \pm 0.02$ & NS \\
$\quad$ (nmol/liter) & Basal & $0.12 \pm 0.01$ & $0.11 \pm 0.01$ & NS \\
& Insulin & $0.51 \pm 0.03$ & $0.57 \pm 0.05$ & NS \\
C-peptide & Fasting & $0.94 \pm 0.11$ & $0.99 \pm 0.13$ & NS \\
(nmol/liter) & Basal & $0.99 \pm 0.11$ & $0.94 \pm 0.13$ & NS \\
& Insulin & $0.75 \pm 0.09$ & $0.84 \pm 0.11$ & NS \\
& & & &
\end{tabular}

Fasting values are before administration of Acipimox/placebo. Basal and insulin values are mean values of four determinations during the basal and insulin-stimulated $\left(40 \mathrm{mU} / \mathrm{m}^{2}\right.$ per $\left.\mathrm{min}\right)$ steady-state periods. Data are mean \pm SE.

higher on the day where patients received Acipimox, this difference was not statistically significant. Plasma insulin and C-peptide concentrations were the same on both study days during both steady-state periods. Plasma concentrations of insulin and C-peptide were constant during the predefined basal and insulin stimulated steady-state periods, indicating that steady state was achieved during these two intervals. The mean coefficients of variation of plasma glucose concentrations during insulin infusion were $3 \%$ during placebo studies and $2 \%$ Acipimox studies.

Acipimox significantly lowered plasma concentrations of triglycerides and NEFA during the basal steady-state period and during the insulin-stimulated steady-state period (Table III). The mean coefficient of variation of plasma NEFA concentrations during insulin infusion was $12 \%$ during placebo studies and 15\% during Acipimox studies. Acipimox increased plasma concentrations of lactate during both steady-state periods.

The $\mathrm{CO}_{2}$ concentrations under the hood during indirect calorimetry measurements remained constant and did not exceed $1 \%$ at any time point during the steady-state periods. Lipid oxidation (Fig. 2) was inhibited by Acipimox in all patients in the basal state $\left(20 \pm 2\right.$ vs. $33 \pm 3 \mathrm{mg} / \mathrm{m}^{2}$ per min, $\left.P<0.01\right)$ and during insulin infusion $\left(8 \pm 2\right.$ vs. $17 \pm 2 \mathrm{mg} / \mathrm{m}^{2}$ per min, $P$ $<0.01$ ). Concurrently, glucose oxidation (Fig. 2) was stimulated by Acipimox in all patients in the basal state (76 \pm 4 vs. $50 \pm 4 \mathrm{mg} / \mathrm{m}^{2}$ per $\left.\mathrm{min}, P<0.01\right)$ and during insulin infusion $\left(121 \pm 7\right.$ vs. $95 \pm 4 \mathrm{mg} / \mathrm{m}^{2}$ per $\left.\min , P<0.01\right)$. Note that the stimulatory effect of Acipimox and insulin on glucose oxidation was completely additive; i.e., Acipimox increased glucose oxidation with $26 \mathrm{mg} / \mathrm{m}^{2}$ per min in both the basal state and during insulin infusion. The decrease in lipid oxidation caused by Acipimox was inversely correlated with the increase in glucose oxidation in the basal state $(r=-0.74, P<0.01)$ and during insulin infusion $(r=-0.76, P<0.01)$. On the placebo day, insulin was unable to stimulate energy expenditure $(5.2 \pm 0.2$ vs. $5.2 \pm 0.2 \mathrm{~kJ} / \mathrm{min})$, whereas on the day where patients received Acipimox, insulin significantly stimulated energy expenditure $(5.1 \pm 0.2$ vs. $5.4 \pm 0.2 \mathrm{~kJ} / \mathrm{min}, P<0.02)$.

Plasma concentrations of $\left[3-{ }^{3} \mathrm{H}\right]$ glucose were constant during both basal and insulin-stimulated steady-state periods, in- dicating that isotopically steady states were really achieved. In the basal state, Acipimox did not affect total peripheral glucose uptake (Acipimox vs. placebo $97 \pm 3$ vs. $94 \pm 4 \mathrm{mg} / \mathrm{m}^{2}$ per min, NS, Fig. 2). During insulin infusion, however, Acipimox increased total peripheral glucose uptake in all patients $(369 \pm 49$ vs. $262 \pm 31 \mathrm{mg} / \mathrm{m}^{2}$ per min, $P<0.01$, Fig. 2 ).

Owing to an increased glucose oxidation and an unaffected total peripheral glucose uptake, Acipimox significantly inhibited nonoxidative glucose metabolism in the basal state $(21 \pm 5$ vs. $44 \pm 5 \mathrm{mg} / \mathrm{m}^{2}$ per min, $P<0.02$, Fig. 2). During insulin infusion, however, Acipimox had a marked stimulatory effect on nonoxidative glucose metabolism $(248 \pm 47 \mathrm{vs} .167 \pm 29 \mathrm{mg} /$ $\mathrm{m}^{2}$ per min, $P<0.01$, Fig. 2). No correlation was found between the inhibitory effect of Acipimox on lipid oxidation and the stimulatory effect of Acipimox on nonoxidative glucose disposal during insulin infusion ( $r=0.07, \mathrm{NS})$.

HGP was unaffected by Acipimox in the basal state (placebo vs. Acipimox, $86 \pm 2$ vs. $91 \pm 3 \mathrm{mg} / \mathrm{m}^{2}$ per min, NS) and was completely suppressed by insulin on both the day where patients received placebo $\left(-72 \pm 17 \mathrm{mg} / \mathrm{m}^{2}\right.$ per min) and Acipi$\operatorname{mox}\left(-74 \pm 31 \mathrm{mg} / \mathrm{m}^{2}\right.$ per $\left.\mathrm{min}\right)$.

Acipimox increased the activity of glycogen synthase $\left(\mathrm{FV}_{0.1}\right)$ in biopsies from skeletal muscles in the basal state and during insulin infusion (Table IV). Furthermore, the physiological insulin stimulation in the present study $\left(40 \mathrm{mU} / \mathrm{m}^{2}\right.$ per $\mathrm{min}$ ) was able to increase the activity of glycogen synthase $\left(F V_{0.1}\right)$ on both study days. No effect of Acipimox or insulin was seen on total GS activity.

Insulin activated PDHa, whereas PDHt was unaffected by insulin (Table IV). Thus, the PDH activity ratio PDHa/PDHt increased during the insulin infusion. Surprisingly, no effect of Acipimox was seen on the activity of PDHa or PDHt. Furthermore, no effect of Acipimox was seen on the activity of PFK either in the basal state or during insulin infusion (Table IV). Insulin had no effect on the activity of PFK.

Intracellular concentrations of free glucose, G-6-P, glycogen, and lactate in skeletal muscles are given in Table V. Acipimox or insulin had no effect on intracellular concentrations of

Table III. Effect of Acipimox on Plasma Triglyceride, NEFA, and Lactate Concentrations in 12 Patients with NIDDM during a Basal Postprandial State and during Insulin Infusion $\left(40 \mathrm{mU} / \mathrm{m}^{2}\right.$ per $\left.\mathrm{min}\right)$

\begin{tabular}{|c|c|c|c|}
\hline & & Placebo & Acipimox \\
\hline \multirow{3}{*}{$\begin{array}{l}\text { Triglycerides } \\
\text { (mmol/liter) }\end{array}$} & Fasting & $2.57 \pm 0.45$ & $2.48 \pm 0.37$ \\
\hline & Basal & $2.56 \pm 0.49$ & $2.18 \pm 0.30$ \\
\hline & Insulin & $2.29 \pm 0.47$ & $1.84 \pm 0.31$ * \\
\hline \multirow{3}{*}{$\begin{array}{l}\text { NEFA } \\
\qquad(\mathrm{mmol} / \text { liter })\end{array}$} & Fasting & $0.64 \pm 0.06$ & $0.63 \pm 0.08$ \\
\hline & Basal & $0.70 \pm 0.04$ & $0.12 \pm 0.0^{\ddagger 8}$ \\
\hline & Insulin & $0.09 \pm 0.02^{8}$ & $0.05 \pm 0.01$ \\
\hline \multirow{3}{*}{$\begin{array}{l}\text { Lactate } \\
\qquad(\mathrm{mmol} / \text { liter })\end{array}$} & Fasting & $0.73 \pm 0.12$ & $0.81 \pm 0.06$ \\
\hline & Basal & $0.78 \pm 0.05$ & $0.87 \pm 0.07^{*}$ \\
\hline & Insulin & $0.91 \pm 0.04$ & $1.07 \pm 0.10^{* \$}$ \\
\hline
\end{tabular}

Fasting values are before administration of Acipimox/placebo. Basal and insulin values are mean values of four determinations during the basal and insulin-stimulated steady-state periods. Data are mean $\pm \mathrm{SE}$. ${ }^{*} P<0.05$ vs. placebo; ${ }^{\ddagger} P<0.01$ vs. placebo; and ${ }^{8} P<0.01$ vs. fasting levels. 




Figure 2. Effect of Acipimox on lipid oxidation, glucose oxidation, total peripheral glucose disposal, and nonoxidative glucose disposal in the basal state and during insulin infusion in 12 subjects with NIDDM. Data are mean \pm SE.

either free glucose, G-6-P, or lactate. The unaffected lactate concentration in skeletal muscles is in contrast to the increased concentration of lactate in plasma on the day where patients received Acipimox. Insulin increased the concentration of glycogen in skeletal muscles on both study days, whereas there was no significant difference in glycogen concentration between the days where patients received Acipimox or placebo.

\section{Discussion}

In the present study we have demonstrated a marked acute improvement of insulin action in patients with NIDDM by giving the antilipolytic NA analogue Acipimox. The improved insulin action was due to both a stimulatory effect of Acipimox on glucose oxidation and on nonoxidative glucose disposal. Acipimox acutely inhibited lipid oxidation and stimulated glucose oxidation in the basal state and during insulin stimulation. The effect of Acipimox on lipid oxidation was highly negatively correlated with the effect of Acipimox on glucose oxidation in the basal state and during insulin infusion. In contrast, the effect of Acipimox on lipid oxidation was not correlated with the effect of Acipimox on insulin-stimulated nonoxidative glucose metabolism. Furthermore, in the basal state Acipimox had no effect on peripheral glucose uptake, and thus we actually found that Acipimox decreased nonoxidative glucose disposal in the basal state.

Through using indirect calorimetry, measurements of carbohydrate and lipid oxidation represent net rates of utilization (19). This means that an increase in de novo lipogenesis in the liver or adipose tissue, unaccompanied by changes in lipid or glucose oxidation, could be misinterpreted as a decrease in the rate of lipid oxidation and/or an increase in the rate of glucose oxidation. Therefore, it could be claimed that the effects of Acipimox on lipid and glucose oxidation in the present study partly could be due to a stimulatory effect of Acipimox on de novo fatty acid synthesis. We are, however, unaware of any data indicating that Acipimox may increase de novo lipogenesis. Furthermore, preliminary in vitro experiments on isolated adipocytes during different insulin concentrations have failed to show any stimulatory effect of Acipimox on glucose uptake in this tissue (J. Vinten, personal communication). This suggests that Acipimox may not stimulate de novo lipogenesis, at least not in adipose tissue. However, it is important to emphasize that an overestimation of the effect of Acipimox on glucose oxidation would mean a corresponding underestimation of Acipimox on the nonoxidative glucose disposal. Thus, the stimulatory effect of Acipimox on insulin-stimulated nonoxidative glucose disposal, which in fact was the quantitatively most important, may have been even greater than demonstrated in the present study.

In vivo studies in humans have demonstrated that infusion of intralipid (a triglyceride emulsion) with heparin during different degrees of insulinization causes increased lipid oxidation and decreased glucose oxidation in normal subjects (5) and in patients with NIDDM (43). The present in vivo data demonstrates that the glucose-fatty acid cycle also operates the other way round in patients with NIDDM. The tissue, however, which is responsible for the in vivo effects of Acipimox on glucose oxidation, remains obscure. If a true inverse Randle's cycle in skeletal muscles was responsible for the in vivo effects of Acipimox on glucose oxidation in the present study, one would have expected increased activities of PDH and PFK in biopsies from skeletal muscles. Furthermore, decreased intracellular concentrations of free glucose and G-6-P in skeletal muscles would have been expected. No effect of Acipimox on any of these enzyme activities or substrate concentrations were detected in the basal state or during insulin infusion in this study, suggesting that the in vivo effect of Acipimox on glucose oxidation was not due to an increased oxidation of glucose in skeletal muscles. The fact that the effect of Acipimox on glucose oxidation was seen in both the basal state and during insulin infusion, and furthermore, that the stimulatory effect of Acipimox on glucose oxidation was exactly the same in both situations $\left(26 \mathrm{mg} / \mathrm{m}^{2}\right.$ per $\left.\mathrm{min}\right)$ demonstrates that this effect is

Table IV. Effect of Acipimox on Activities of the Key Enzymes GS, PDH, and PFK in Biopsies from Skeletal Muscles in 12 Patients with NIDDM during a Postprandial Basal State and during Insulin Infusion $\left(40 \mathrm{mU} / \mathrm{m}^{2} / \mathrm{min}\right)$

\begin{tabular}{|c|c|c|c|c|}
\hline & \multicolumn{2}{|c|}{ Basal } & \multicolumn{2}{|c|}{ Insulin } \\
\hline & Placebo & Acipimox & Placebo & Acipimox \\
\hline & \multicolumn{4}{|c|}{ nmol/ UDPG/min per ng protein } \\
\hline GS (0.1 mM G-6-P) & $2.3 \pm 0.5$ & $3.0 \pm 0.6^{*}$ & $4.1 \pm 0.6^{5}$ & $4.9 \pm 0.8 * 8$ \\
\hline GS (10.0 mM G-6-P) $\}$ & $9.1 \pm 1.6$ & $9.3 \pm 1.6$ & $9.9 \pm 1.1$ & $9.9 \pm 1.1$ \\
\hline \multirow[t]{2}{*}{ GS FV $0.1(\%)$} & $25 \pm 3$ & $32 \pm 2^{*}$ & $41 \pm 4^{5}$ & $50 \pm 5^{* 5}$ \\
\hline & \multicolumn{4}{|c|}{ pmol pyruvate/min per mg protein } \\
\hline PDHa & $301 \pm 68$ & $226 \pm 47$ & $406 \pm 35^{\ddagger}$ & $361 \pm 38^{\ddagger}$ \\
\hline PDHt & $521 \pm 70$ & $448 \pm 53$ & $546 \pm 48$ & $443 \pm 49$ \\
\hline \multirow[t]{2}{*}{ PDHa/PDHt (\%) } & $58 \pm 7$ & $50 \pm 9$ & $74 \pm 4^{\ddagger}$ & $81 \pm 4^{\ddagger}$ \\
\hline & \multicolumn{4}{|c|}{$n m o l$ F-6-P/min per mg protein } \\
\hline PFK (0.1 mM F-6-P) & $101 \pm 12$ & $105 \pm 11$ & $116 \pm 13$ & $106 \pm 11$ \\
\hline PFK (2.0 mM F-6-P) & $136 \pm 14$ & $137 \pm 14$ & $155 \pm 16$ & $143 \pm 15$ \\
\hline
\end{tabular}

Data are mean \pm SE. ${ }^{*} P<0.05$ vs. placebo; ${ }^{\ddagger} P<0.05$ vs. basal; and \$ $P<0.01$ vs. basal. 
Table V. Effect of Acipimox on Intracellular Concentrations of Free Glucose, G-6-P, Lactate, and Glycogen in Skeletal Muscles in 12 Patients with NIDDM

\begin{tabular}{|c|c|c|c|c|c|}
\hline & & \multicolumn{2}{|c|}{ Basal } & \multicolumn{2}{|c|}{ Insulin } \\
\hline & & Placebo & Acipimox & Placebo & Acipimox \\
\hline Glucose ) & & $0.24 \pm 0.15$ & $0.33 \pm 0.15$ & $0.18 \pm 0.16$ & $0.24 \pm 0.21$ \\
\hline G-6-P & (mmol/liter intracellular water) & $0.10 \pm 0.04$ & $0.08 \pm 0.02$ & $0.10 \pm 0.03$ & $0.07 \pm 0.01$ \\
\hline Lactate & & $2.77 \pm 0.41$ & $2.43 \pm 0.37$ & $3.41 \pm 0.46$ & $2.74 \pm 0.32$ \\
\hline Glycogen & $(\mathrm{mmol} / \mathrm{kg} d r y w t)$ & $364 \pm 19$ & $367 \pm 33$ & $389 \pm 19^{*}$ & $463 \pm 74^{*}$ \\
\hline
\end{tabular}

Concentration of glucose, G-6-P, and lactate are given as millimoles per liter of intracellular water. Calculation of these concentrations are based on the assumptions of an extracellular water content in the muscle biopsies of $0.3 \mathrm{l} / \mathrm{kg}$ dry weight and an intracellular water content of $2.8 \mathrm{l} / \mathrm{kg}$ dry weight. Glycogen is given as millimoles per kilogram of dry weight. Data are mean $\pm \mathrm{SE} .{ }^{*} P<0.01$ vs. basal.

independent of the degree of insulinization. This could be taken as an indirect evidence for that the effect of Acipimox on whole-body glucose oxidation may not necessarily be located to an insulin-sensitive tissue. This is consistent with data from animal studies that the glucose-fatty acid cycle operates in nonmuscle tissue such as kidney and liver (44).

We did, however, find a significant stimulation of the PDH activity during insulin infusion on both study days. This may suggest that the increase in whole-body glucose oxidation seen on both study days during insulin infusion could be due to an increase in glucose oxidation in skeletal muscles.

An alternative explanation for the lack of effect of Acipimox on PDH and PFK activities, and on concentrations of free glucose and G-6-P, could be that the mechanisms regulating glucose oxidation in human skeletal muscles are different from the mechanisms which were pointed out by Randle and coworkers on perfused rat hearts and hemidiaphragms. It is important to emphasize that the regulatory mechanisms suggested by Randle have never been demonstrated to operate in human skeletal muscles. In addition, several investigations have failed to show inhibitory effects of NEFA on glucose utilization in various animal skeletal muscle preparations (45-50).

An alternative mechanism, by which Acipimox may stimulate glucose oxidation in human skeletal muscle could be through a direct stimulation of glucose transport over the cell membrane. An increased glucose transport over the cell membrane may enhance the flux through glycolysis and the citric acid cycle, thus increasing glucose oxidation. If this was the mechanism, enzyme activities and substrate concentrations in biopsies from skeletal muscles could be unaffected by Acipimox despite an increased glucose oxidation in the tissue. In fact, NA has been shown to increase glucose transport into rat adipocytes under in vitro experimental conditions (51). We found that Acipimox increased peripheral glucose uptake during insulin infusion, but not in the basal state. Thus, an increased glucose transport into the muscle cell could explain the increase in glucose oxidation during insulin infusion, but not in the basal state. The increase in glucose oxidation, however, was exactly the same in the basal state and during insulin infusion, suggesting identical stimulatory mechanisms in the two states. Therefore, an increased glucose transport over the muscle cell membrane is unlikely to be the explanation for the increase in glucose oxidation caused by Acipimox.

The key point in the Randle's cycle is PDH. This enzyme exists in a phosphorylated less active and a dephosphorylated more active form. The fractional activity of PDH (PDHa/ PDHt) is decreased by starvation or induction of alloxan-diabetes (insulin deficient diabetes) in rat heart, rat skeletal muscle, rat liver, rat kidney, and rat adipose tissue (52-56). Randle suggested that the decreased fractional activity of $\mathrm{PDH}$ in skeletal muscles could explain the impaired glucose metabolism in diabetes. This hypothesis was, however, based on data obtained in an insulinopenic model, which in humans resembles insulin-dependent diabetes (IDDM) more than it resembles the hyperinsulinemic syndrome NIDDM. Recently, it was demonstrated by Kelley and Mandarino (57) that PDH activity in skeletal muscles from patients with NIDDM is not decreased compared to normal subjects. Instead, these authors demonstrated an increased skeletal muscle PDH activity during fasting hyperglycemia in patients with NIDDM. The fact that PDH may not be defective in NIDDM may also provide an explanation for the lack of effect of Acipimox on PDH activity. Thus, it has been shown that intravenous administration of the fatty acid oxidation inhibitor 2-tetradecylglycidic acid had no effect on the proportion of PDH complex in the active form in heart, diaphragm or gastrocnemius muscles or in liver, kidney, or adipose tissue of fed normal rats (58). However, the fatty acid oxidation inhibitor was able to reverse effects of starvation and alloxan-diabetes on the proportion of active PDH complex in heart muscle.

Acipimox had no effect on peripheral glucose uptake in the basal state, whereas during insulin infusion Acipimox had a marked stimulatory effect on peripheral glucose uptake. In other words, Acipimox improved insulin action in the NIDDM patients. The quantitatively most important part of this effect was on the insulin-stimulated nonoxidative glucose uptake. Under insulin-stimulated conditions, nonoxidative glucose metabolism is thought to primarily represent muscle glycogen synthesis (59) and is correlated with the activity of skeletal muscle GS in normal subjects and in patients with $\operatorname{NIDDM}(28,59,60)$. We found that Acipimox increased the activity of GS in skeletal muscles in the basal state and during insulin infusion. Thus, during insulin infusion, the increased activity of GS in skeletal muscles may be responsible for the increased whole-body nonoxidative glucose metabolism. In the basal state, however, we found an increase in muscle GS activity, which was not reflected by an increase in whole-body nonoxidative glucose disposal. In contrast, we found a slight decrease in nonoxidative glucose uptake in the basal state. This apparently paradoxical phenomenon may be explained by the 
fact that, in the basal postabsorptive state, skeletal muscle is responsible for only a small part $(<20 \%)$ of the total peripheral glucose uptake (61). In contrast, skeletal muscle is responsible for the majority of peripheral glucose uptake during high physiological insulin concentrations (61). Thus, in the basal state whole body nonoxidative glucose uptake may represent other biochemical pathways than glycogen synthesis in skeletal muscles. Such pathways could be either lipogenesis or the pentose phosphate shunt in the liver or in adipose tissue.

Lactate formation from glycolysis is a further nonoxidative pathway, which operates in most tissues. Acipimox slightly increased plasma concentrations of lactate in the basal state and during insulin infusion. Thus, increased lactate formation may also be responsible for the increased nonoxidative glucose metabolism during insulin infusion. Because intracellular muscle lactate concentrations were unaffected (or slightly decreased) by Acipimox, however, the increased plasma lactate concentration is not likely to be due to increased lactate formation in skeletal muscles. Furthermore, the possibility that the increased plasma lactate concentration during Acipimox studies could be due to an impaired uptake of lactate in liver or muscle cannot be excluded from the present data.

An important question is now whether the increase in nonoxidative glucose metabolism and GS activity was caused by a lower tissue availability of free fatty acids, or whether this was an effect of the drug per se. This question may be important not only for the understanding of the pharmacological action of Acipimox, but also for the understanding of the impaired insulin action in NIDDM. This is further illustrated by the fact that the impaired insulin-stimulated nonoxidative glucose disposal may be of primary (i.e., genetic) origin in NIDDM (62). The influence of free fatty acids on nonoxidative glucose metabolism is controversial. Infusion of intralipid with heparin has been shown to inhibit nonoxidative glucose metabolism in normal subjects (5). In obese subjects (63) and in patients with NIDDM (44), however, infusion of intralipid did not inhibit nonoxidative glucose disposal. In the present study, no correlation between the effect of Acipimox on lipid oxidation and nonoxidative glucose disposal was demonstrated. This suggests that a pure effect of a lower NEFA availability may not solely explain the effect of Acipimox on nonoxidative glucose disposal. Furthermore, Randle and co-workers did not demonstrate any inhibitory effect of NEFA on glycogen synthesis on the perfused rat hearts and hemidiaphragms. This is in contrast to a very recent publication, where elevated concentrations of NEFA were shown to inhibit glycogen synthesis in an in vitro human muscle strip preparation (64). Acipimox inhibits lipolysis in adipose tissue by lowering intracellular concentrations of cyclic AMP (65). If this is also the case in skeletal muscles, Acipimox may decrease the activity of the cyclic AMP-dependent protein kinase by this mechanism. This may cause an increase in GS activity due to an increased proportion of GS being on the more active dephosphorylated form. Thus, it is presently unclear whether the effect of Acipimox on GS activity is direct or indirect elicited by changes in NEFA.

In previous studies, nicotinic acid has been shown to both increase and decrease plasma glucose concentration in normal and diabetic humans and animals $(7,66-74)$. The reason for these discrepancies is not clear. The most obvious explanation for this is the rebound in plasma NEFA levels noted to occur with chronic administration of NA. Thus, most acute experi- ments with NA have found a beneficial effect on glucose metabolism, while most chronic experiments have revealed a deterioration (diabetogenic effect) on glucose metabolism. Other explanations for the different effects of NA on glucose metabolism in different studies could be species differences or a question of doses. However, if the problem lies in the rebound effect in plasma NEFA levels, Acipimox may also have potential beneficial effects on glucose metabolism in NIDDM patients with chronic treatment, owing to the less tendency to cause this rebound effect (15). A long-term study is required to answer this question.

In conclusion, acute inhibition of lipolysis with Acipimox improved insulin action in patients with NIDDM by increasing both insulin-stimulated glucose oxidation and nonoxidative glucose disposal. This supports the hypothesis that elevated NEFA levels may be important for the development of insulin resistance in NIDDM. The increase in nonoxidative glucose disposal was the quantitatively most important and was probably caused by an increased activity of GS in skeletal muscles. The increase in glucose oxidation was seen both in the basal state and during insulin infusion and could not be attributed to increased activities of PDH and/or PFK in skeletal muscles. This suggests that nonmuscle tissues may be responsible for the increase in glucose oxidation caused by Acipimox. A long-term study with Acipimox is required to demonstrate whether the acute beneficial effect on glucose metabolism can also lead to a long-term improvement of metabolic control in NIDDM patients.

\section{Acknowledgments}

The authors would like to acknowledge the expert technical assistance of Karen Arvad, Bente Hansen, Bente Mottlau, and Annemette Forman.

This study was supported by grants from the Danish Medical Research Council, the Danish Diabetes Association, the Velux Foundation and Farmitalia Carlo Erba, Milano, Italy.

\section{References}

1. Greenfield, M., O. Kolterman, J. Olefsky, and G. M. Reaven. 1980. Mechanism of hypertriglyceridaemia in patients with fasting hyperglycaemia. Diabetologia. 18:441-446.

2. Reaven, G. M., and M. S. Greenfield. 1981. Diabetic hypertriglyceridaemia: evidence for three clinical syndromes. Diabetes. 30:66-75.

3. Bogardus, C., S. Lillioja, B. V. Howard, G. M. Reaven, and D. Mott. 1984. Relationships between insulin secretion, insulin action and fasting plasma glucose concentration in nondiabetic and non-insulin-dependent diabetic subjects. J. Clin. Invest. 74:1238-1246.

4. Golay, A., Y. D. I. Chen, and G. M. Reaven. 1986. Effect of differences in glucose tolerance on insulins' ability to regulate carbohydrate and free fatty acid metabolism in obese individuals. J. Clin. Endocrinol. Metab. 62:1081-1088.

5. Thiébaud, D., R. A. DeFronzo, E. Jacot, A. Golay, K. Acheson, E. Maeder, E. Jéquier, and J. P. Felber. 1982. Effect of long chain triglyceride infusion on glucose metabolism in man. Metab. Clin. Exp. 31:1128-1136.

6. Ferrannini, E., E. J. Barret, S. Bevilacqua, and R. A. DeFronzo. 1983. Effect of fatty acids on glucose production and utilization in man. J. Clin. Invest. 72:1737-1747.

7. Reaven, G. M., H. Chang H. Ho, C. Y. Jeng and B. Hoffman. 1988. Lowering of plasma glucose in diabetic rats by antilipolytic agents. Am. J. Physiol. 254:E23-30.

8. Randle, P. J., P. B. Garland, C. N. Hales, and E. A. Newsholme. 1963. The glucose fatty-acid cycle: its role in insulin sensitivity and the metabolic disturbances of diabetes mellitus. Lancet. $i$ : 785-789.

9. Garland, P. B., E. A. Newsholme, and P. J. Randle. 1964. Regulation of glucose uptake by muscle: effects of fatty acids and ketone bodies, and of alloxandiabetes and starvation, on pyruvate metabolism and lactate/pyruvate and L- 
glycerol-3-phosphate/dihydroxyacetone phosphate concentration ratios in rat heart and rat diaphragm muscles. Biochem. J. 93:665-678.

10. Garland, P. B., and P. J. Randle. 1964. Regulation of glucose uptake by muscle: effects of alloxan-diabetes, starvation, hypophysectomy and adrenalectomy, and of fatty acids, ketone bodies and pyruvate, on the glycerol output and concentrations of free fatty acids, long-chain fatty acyl-coenzyme A, glycerol phosphate and citrate-cycle intermediates in rat heart and diaphragm muscles. Biochem. J. 93:678-687.

11. Randle, P. J., P. J. England, and R. M. Denton. 1970. Control of the tricarboxylate cycle and its interactions with glycolysis during acetate utilization in rat heart. Biochem. J. 117:677-695.

12. Kerbey, A. L., P. M. Radcliffe, P. J. Randle, and P. H. Sugden. 1979. Regulation of kinase reactions in pig heart pyruvate dehydrogenase complex. Biochem. J. 181:427-433.

13. Newsholme, E. A., P. H. Sugden, and T. Williams. 1977. Effect of citrate on the activities of phosphofructokinase from nervous and muscle tissue from different animals and its relationship to the regulation of glycolysis. Biochem. $J$. 166:123-129.

14. Musatti, L., E. Maggi, E. Moro, G. Valzelli and V. Tamassia. 1981. Bioavailability and pharmacokinetics of Acipimox, a new antilipolytic and hypolipidaemic agent. J. Int. Med. Res. 9:381-386.

15. Fucella, L. M., G. Goldaniga, P. Lovisolo, E. Maggi, L. Musatti, V. Mandelli, and C. R. Sirtori. 1980. Inhibition of lipolysis by nicotinic acid and by Acipimox. Clin. Pharmacol. Ther. 28:790-795.

16. McGuire, E. A. H., J. H. Helderman, J. D. Tobin, R. Andres, and M. Berman. 1976. Effects of arterial versus venous sampling on analysis of glucose kinetics in man. J. Appl. Physiol. 55:628-634.

17. DeFronzo, R. A., J. D. Tobin, and R. Andres. 1979. Glucose clamp technique: a method for quantifying insulin secretion and resistance. Am. J. Physiol. 232:E214-223.

18. Hother-Nielsen, O., and H. Beck-Nielsen. 1990. On determination of basal glucose production rate in patients with type 2 (non-insulin dependent) diabetes using primed-continuous $3-{ }^{3} \mathrm{H}$-glucose infusion. Diabetologia. 33:603610 .

19. Frayn, K. N. 1983. Calculation of substrate oxidation rates in vivo from gaseous exchange. J. Appl. Physiol. 55:628-634.

20. Ferrannini, E. 1983. The theoretical basis of indirect calorimetry: a review. Metab. Clin. Exp. 37:287-301.

21. Tappy, L., O. E. Owen, and G. Boden. 1988. Effect of hyperinsulinemia on urea pool size and substrate oxidation rates. Diabetes. 37:1212-1216.

22. Steele, R. 1959. Influence of glucose loading and of injected insulin on hepatic glucose output. Ann. NY. Acad. Sci. 82:420-430.

23. Cowan, J. S., and S. Hetenyi. 1971 . Glucoregulatory responses in normal and diabetic dogs recorded by a new tracer method. Metab. Clin. Exp. 20:360372.

24. Cobelli, C., A. Mari, and E. Ferrannini. 1987. Non-steady state: error analysis of Steele's model and development for glucose kinetics. Am. J. Physiol. 252:E679-689.

25. Lowry, O. H., and J. V. Passoneau. 1972. A Flexible System of Enzymatic Analysis. Academic Press, Inc., New York.

26. Sjøgaard, G., R. P. Adams, and B. Saltin. 1985. Water and ion shifts in skeletal muscle of humans with intense dynamic knee extension. Am. J. Physiol. 248 (Regul. Integrative Comp. Physiol. 17): R190-R196.

27. Sjøgaard, G., and B. Saltin. 1982. Extra- and intracellular water spaces in muscles in man at rest and with dynamic exercise. Am. J. Physiol. 243 (Regul. Integrative Comp. Physiol. 12):R271-R280.

28. Mandarino, L., K. Wright, L. Verity, J. Nichols, J. Bell, O. Kolterman, and $H$. Beck-Nielsen. 1987. Effects of insulin infusion on human skeletal muscle pyruvate dehydrogenase, phosphofructokinase, and glycogen synthase. J. Clin. Invest. 80:655-63.

29. Hagg, S. A., S. I. Taylor, and N. B. Ruderman. 1976. Glucose metabolism in perfused skeletal muscle: pyruvate dehydrogenase activity in starvation, diabetes and exercise. Biochem. J. 158:203-210.

30. Blass, J. P., J. Avigan, and B. W. Uhlendorf. 1970. A defect in pyruvate decarboxylase in a child with an intermittent movement disorder. J. Clin. Invest. 49:423-432.

31. Wieland, O. H. 1983. The mammalian pyruvate dehydrogenase complex; structure and regulation. Rev. Physiol. Biochem. Pharmacol. 96:123-170.

32. Thomas, J., K. Schlender, and J. Larner. 1968. A rapid filter paper assay for UDP-glucose-glycogen glucosyltransferase, including an improved biosynthesis of UDP- ${ }^{14} \mathrm{C}$-glucose. Anal. Biochem. 25:486-499.

33. Beutler, E. 1971. Phosphofructokinase. In Red Cell Metabolism: A Manual of Biochemical Methods. E. Beutler, editor. Grune \& Stratton, Inc., New York. 42-44.

34. Lowry, O. H., N. J. Rosebrough, A. L. Farr, and R. J. Randall. 1951 Protein measurements with Folin phenol reagent. J. Biol. Chem. 193:265-272.

35. Andersen, I., and S. Hannibal. 1983. Analytical and economical optimization of a glucose method with immobilized enzymes. J. Autom. Chem. 5:188192.
36. Somogyi, M. 1945. Determination of blood sugar. J. Biol. Chem. 160:69 73.

37. Heding, L. G. 1972. Determination of total serum insulin (IRI) in insulintreated diabetic patients. Diabetologia. 8:260-266.

38. Heding, L. G. 1975. Radioimmunological determination of human Cpeptide in serum. Diabetologia. 11:541-548.

39. Itaya, K., and U. Michio. 1965. Colorimetric determination of free fatty acids in biological fluids. J. Lipid Res. 6:16-20.

40. Passonneau, J. V. 1974. L-(+)-lactate: fluorometric method. In Methods of Enzymatic Analysis. Volume 3. H. V. Bergmeyer, editor. Academic Press, Inc. New York. 1468-1472.

41. Mortensen, H. B. 1980. Quantitative determination of hemoglobin $A_{k}$ by thin layer isoelectric focusing. $J$. Chromatogr. 182:325-333.

42. Flenberg, S. E. 1978. The Analysis of Cross-classified Data. MIT Press, Cambridge, MA.

43. Bevilacqua, S., G. Buzzigoli, R. Bonadonna, L. S. Brandi, M. Oleggini, C Boni, M. Geloni, and E. Ferrannini. 1990. Operation of Randle's cycle in patients with NIDDM. Diabetes. 39:383-389.

44. Randle, P. J., A. L. Kerbey, and J. Espinal. 1988. Mechanisms decreasin glucose oxidation in diabetes and starvation: Role of lipid fuels and hormones. Diabetes Metab. Rev. 4:623-638.

45. Beatty, C. H., and R. M. Bocek. 1971. Interrelation of carbohydrate and palmitate metabolism in skeletal muscle. Am. J. Physiol. 220:1928-1934.

46. Jefferson, L. S. J., J. O. Kochler, and H. E. Morgan. 1972. Effect of insulin on protein synthesis in skeletal muscle of isolated perfused preparation of rat hemicorpus. Proc. Natl. Acad. Sci. USA. 69:816-820.

47. Goodman, M. N., M. Berger, and N. Ruderman. 1974. Glucose metabolism in rat skeletal muscle at rest. Diabetes. 23:881-888.

48. Reimer, F., G. Loffler, G. Hennig, and O. H. Wieland. 1975. The influence of insulin on glucose and fatty acid metabolism in the isolated perfused hindquarter. Hoppe Seylers Z. Physiol. Chem. 356:1055-1066.

49. Maizels, E. Z., N. B. Ruderman, M. N. Goodman, and D. Lau. 1977. Effect of acetoacetate on glucose metabolism in the soleus and extensor digitorum longus muscles of the rat. Biochem. J. 162:557-568.

50. Richter, E. A., N. B. Ruderman, H. Gavras, E. R. Belur, and H. Galbo. 1982. Muscle glycogenolysis during exercise: dual control by epinephrine and contractions. Am. J. Physiol. 242 (Endocrinol. Metab. 5): E25-E32.

51. Wayne, M. T., and M. L. Halperin. 1979. Stimulation of glucose transport in rat adipocytes by insulin, adenosine, nicotinic acid and hydrogen peroxide. Biochem. J. 178:381-389.

52. Randle, P. J., P. H. Sugden, A. L. Kerbey, P. M. Radcliffe, and N. J. Hutson. 1978. Regulation of pyruvate oxidation and the conservation of glucose. Biochem. Soc. Symp. 43:47-67.

53. Hennig G., G. Löffler, and O. H. Wieland. 1975. Active and inactive forms of pyruvate dehydrogenase in skeletal muscle as related to the metabolic and functional state of the muscle cell. FEBS (Fed. Eur. Biochem. Soc.) Lett. 59:142-145.

54. Stansbie, D., R. M. Denton, B. J. Bridges, H. T. Pask, and P. J. Randle. 1976. The regulation of pyruvate dehydrogenase and pyruvate dehydrogenase phophate phosphatase activity in rat epididydimal fat pads: effect of starvation, alloxan-diabetes and high fat diet. Biochem. $J .154: 225-236$.

55. Wieland, O. H., E. A. Siess, F. H. Schulze-Wethmar, H. G. von Funcke, and $B$. Winton. 1971. Active and inactive forms of pyruvate dehydrogenase in rat heart and kidney: effect of diabetes, fasting, and refeeding on pyruvate dehydrogenase interconversion. Arch. Biochem. Biophys. 143:593-601.

56. Wieland, O. H., C. Patzelt, and G. Löffler. 1972. Active and inactive forms of pyruvate dehydrogenase in rat liver: effect of starvation and refeeding and of insulin treatment on pyruvate dehydrogenase interconversion. Eur. J. Biochem. 26:426-433.

57. Kelley, D. E., and L. J. Mandarino. 1990. Hyperglycemia normalizes insulin-stimulated skeletal muscle glucose oxidation and storage in non-insulindependent diabetes mellitus. J. Clin. Invest. 86:1999-2007.

58. Caterson, I. D., S. J. Fuller, and P. J. Randle. 1982. Effect of the fatty acid oxidation inhibitor 2-tetradecylglycidic acid on pyruvate dehydrogenase complex activity in starved and alloxan-diabetic rats. Biochem. J. 208:53-60.

59. Bogardus, C., S. Lillioja, K. Stone, and D. Mott. 1984. Correlation between muscle glycogen synthase activity and in vivo insulin action in man. $J$. Clin. Invest. 73:1185-1190.

60. Damsbo, P., A. Vaag, O. Hother-Nielsen, K. Falholdt, and H. Beck-Nielsen. 1989. Lack of glycogen synthase (GS) activation at physiological insulin concentrations in skeletal muscles from obese NIDDM patients. Diabetes. 38:350. (Abstr.)

61. DeFronzo, R. A., E. Jacot, E. Jequier, E. Maeder, J. Wahren, and J. P. Felber. 1981. Results from indirect calorimetry and hepatic and femoral venous catherization. Diabetes. 30:1000-1007.

62. Eriksson, J A. Franssila-Kallunki, A. Ekstrand C. Saloranta, E. Widen C. Schalin, and L. Groop. 1989. Early metabolic defects in persons at increased risk for non-insulin-dependent diabetes mellitus. N. Engl. J. Med. 321:337-343.

63. Bevilacqua, S., R. Bonadonna, G. Buzzigoli, C. Boni, D. Ciociaro, F. 
Maccari, M. A. Giorico, and E. Ferrannini. 1987. Acute elevation of free fatty acid levels leads to hepatic insulin resistance in obese subjects. Metab. Clin. Exp. 36:502-506.

64. Argyraki, M., P. D. Wright, C. W. Venables, G. Proud, and R. Taylor. 1989. In vitro human skeletal muscle strips: effect of nonesterified fatty acid supply on glucose storage. Metab. Clin. Exp. 38:1183-1187.

65. Lovisolo, P. P., G. Briatico-Vangosa, G. Orsini, R. Ronchi, R. Angelucci, and G. Valzelli. 1981. Pharmacological profile of a new anti-lipolytic agent: 5methyl-pyrazine-2-carboxylic acid 4-oxide (Acipimox) (1) I-mechanism of action. Pharmacol. Res. Commun. 13:151-161.

66. Ammon, H. P. T., C. J. Estler, and F. Heim. 1970. Alteration of carbohydrate metabolism in liver, skeletal muscle and brain by nicotinic acid in mice. In Metabolic Effects of Nicotinic Acid and Its Derivatives. K. F. Gey and L. A. Carison, editors. S. Huber, Bern, Switzerland. 799-809.

67. Dzedin, T., N. Svedmyr, and L. Lundholm. 1970. Influence of nicotinic acid on the carbohydrate metabolism: relationship with adrenergic receptors. In Metabolic Effects of Nicotinic Acid and Its Derivatives. K. F. Gey and L. A. Carlson, editors. S. Huber, Bern, Switzerland. 747-751.

68. Felber, J. P., and V. Büber. 1970. Effect of nicotinic acid derivative on glucose levels and glucose tolerance in animal and in man: In Metabolic Effects of Nicotinic Acid and Its Derivatives. K. F. Gey and L. A. Carlson, editors. S. Huber, Bern, Switzerland. 695-710.
69. Froesch, E. R., M. Waldvogel, and O. Olez. 1970. Effects of nicotinic acid and structurally related drugs on adipose tissue in vitro and on carbohydrate and lipid metabolism of normal and diabetic rats in vivo. In Metabolic Effects of Nicotinic Acid and Its Derivatives. K. F. Gey and L. A. Carlson, editors. S. Huber, Bern, Switzerland. 773-794.

70. Gaut, Z. N., H. M. Solomon, and O. N. Miller. 1970. The influence of antilipemic doses of nicotinic acid on carbohydrate tolerance and plasma insulin levels in man. In Metabolic Effects of Nicotinic Acid and Its Derivatives. K. F. Gey and L. A. Carlson, editors. S. Huber, Bern, Switzerland. 923-927.

71. Gaut, Z. N., and W. J. Taylor-Russel. Effects of large doses of nicotinyl alkohol on serum lipid levels and carbohydrate tolerance. J. Clin. Pharmacol. 8:370-376.

72. Gross, R. C., and L. A. Carlson. 1968. Metabolic effects of nicotinic acid in acute insulin deficiency in the rat. Diabetes. 17:353-361.

73. Root, M. A., and J. Ashmore. 1964. The hypoglycemic activity of nicotinic acid in rats. Naunyn-Schmiederebergs Arch. Exp. Pathol. Pharmakol. 248:117-123.

74. Stowers, J. M., P. D. Bewsher, J. M. Stein, and J. Mowat. 1970. Studies on the effects of nicotinic acid given orally or intravenously on oral and intravenous glucose tolerance in man. In Metabolic Effects of Nicotinic Acid and Its Derivatives. K. F. Gey and L. A. Carlson, editors. S. Huber, Bern, Switzerland. 723-731. 